\title{
The prevalence of sickness absence among primary school pupils - reason to be worried?
}

Esther Karen Pijl ${ }^{1,2^{*}}$, Yvonne Theodora Maria Vanneste ${ }^{3}$, Angelique Eveline de Rijk ${ }^{2}$, Frans Joseph Maria Feron ${ }^{2}$ and Jolanda Mathijssen ${ }^{4}$

\begin{abstract}
Background: Absence from school can lead to lower educational achievement and poor health. Little is known about school absence in primary education. This study's first aim was to examine the prevalence of school absence in primary schools and differing types of absence, including sickness absence. The second aim was to determine which pupil characteristics and types of absence were associated with extensive sickness absence.

Methods: The school absence registries for the school year 2015-2016 were analysed retrospectively in eight mainstream primary schools with 2216 pupils, and six schools for special primary education with 1000 pupils in the West-Brabant region of the Netherlands. Descriptive analyses, $x^{2}$-tests, Mann-Whitney $U$ tests and logistic regression analyses were performed.

Results: The one-year prevalence of school absence was $85 \%$ in mainstream primary schools and $79 \%$ in special schools. Sickness absence was the most prevalent type of absence, occurring in 75 and $71 \%$ of pupils, respectively The prevalence of extensive sickness absence was 13 and 23\%, respectively. In mainstream schools, extensive sickness absence was associated with a young age, low parental educational level, more doctor's visits and unauthorised absence, and in special schools with more doctor's visits, other authorised absence, tardiness and unauthorised absence.

Conclusions: The prevalence of extensive sickness absence was high, and as this was associated with other types of absence, these pupils missed even more days of school. Public health research, policy and practice should address sickness absence among primary school pupils, to prevent adverse effects on children's development.
\end{abstract}

Keywords: Primary education, Primary school pupils, School absenteeism, Sickness absence

\footnotetext{
* Correspondence: e.pij|@ggdwestbrabant.nl

${ }^{1}$ Child and Youth Healthcare Department, GGD West-Brabant, Breda, The Netherlands

${ }^{2}$ Department of Social Medicine, Faculty of Health Medicine and Life Sciences, Care and Public Health Research Institute (CAPHRI), Maastricht University, Maastricht, The Netherlands

Full list of author information is available at the end of the article
}

(C) The Author(s). 2021 Open Access This article is licensed under a Creative Commons Attribution 4.0 International License, which permits use, sharing, adaptation, distribution and reproduction in any medium or format, as long as you give appropriate credit to the original author(s) and the source, provide a link to the Creative Commons licence, and indicate if changes were made. The images or other third party material in this article are included in the article's Creative Commons licence, unless indicated otherwise in a credit line to the material. If material is not included in the article's Creative Commons licence and your intended use is not permitted by statutory regulation or exceeds the permitted use, you will need to obtain permission directly from the copyright holder. To view a copy of this licence, visit http://creativecommons.org/licenses/by/4.0/ The Creative Commons Public Domain Dedication waiver (http://creativecommons.org/publicdomain/zero/1.0/) applies to the data made available in this article, unless otherwise stated in a credit line to the data. 


\section{Background}

Absence from school is an important public health issue as it can lead to lower educational achievement, social difficulties, risk behaviour, school dropout, and ultimately, poor health [1-8]. School absence can be caused by underlying problems of both medical and social origin. It has been associated with chronic illness, psychiatric problems, bullying, child abuse, poverty, low parental educational levels and school-related problems [9-20]. Although research often focuses on secondary education, absence from school in primary education impacts educational achievement negatively and the habit of missing school can start during primary education $[7,8,10,21-23]$.

The prevalence of school absenteeism in primary education is unclear. Previous studies have examined varying types of absence (often unauthorised absence or truancy), and have used varying subpopulations (e.g. chronically ill pupils), differing methods of measurement (e.g. mean or median days or absence rates), and differing thresholds to define problematic absence. Depending on the threshold used (varying from 2 to 20 days), reported percentages of problematic absence in primary education lie between 3 and 48\% [10, 24, 25].

This study's first aim is to explore the prevalence of school absence in regular primary education. This exploration was done in the Netherlands where children attend either regular primary education (approximately 95\% of children) or special needs education [26]. There are two types of regular primary education: a mainstream primary school (MPS), and a special school for primary education (SSPE). The latter provides additional support for mild learning difficulties, behavioural problems and parenting problems. Special needs education is for pupils with chronic illness, disabilities or severe learning and behavioural problems. Both MPS and SSPE were included in this study, special needs education schools were not.

Dutch legislation differentiates between unauthorised absence (e.g. truancy) and authorised absence (e.g. absence due to sickness). In the Netherlands, unauthorised absence is overseen by school attendance officers who can use penalties to enforce the law. However, sickness absence is not addressed systematically [27], even though this is the most common type of absence in Dutch secondary education [28]. The situation is hypothesized to be similar in primary education. Pupils who are extensively reported sick (more than nine days or more than four periods in a school year) [29] are likely to be at risk of the negative consequences of absence, as they miss a substantial number of lessons and peer contact. It is important to identify these pupils, so this study's second aim is to gain insight into the characteristics of pupils who are extensively absent due to sickness.
This study examines two research questions.

(i) What is the prevalence of school absenteeism in regular primary education?

(ii) How are pupil characteristics and other types of absence related to extensive sickness absence?

\section{Methods}

\section{Primary schools}

The schools included in the present study were participating in a research project exploring school absence in primary education in the West-Brabant region of the Netherlands. The number of schools approached was based on a power analysis carried out for another study in that research project, for which 10 MPSs were needed.

Regular education schools were included in this study. Special needs schools were excluded as these are intended for pupils with severe physical or psychiatric problems [30], which could seriously influence attendance patterns. A random sample of 16 out of 265 MPSs in the region was selected using a random sample of cases procedure in SPSS. Ten of these schools agreed to participate, eight of which were able to provide data on absence. Seven of the MPSs also provided data on pupil characteristics. All seven SSPEs in the region were asked to participate in the study, six of which agreed to participate and provide all data.

The eight participating MPSs had a total of 2216 pupils at the end of the school year. Three SSPEs did not supply the total number of pupils at the end of the year meaning that the total number of pupils in these three SSPEs at the end of the school year had to be estimated. This was done by taking the official total number of pupils in October 2015 and adding the average increase in pupils (9\%) found in the other three SSPEs. This resulted in 24 additional pupils bringing the total estimated number of pupils in the six SSPEs to 1000.

The median age of pupils in the eight MPSs was 7.4 years. In the municipalities where the eight MPSs were located, $50 \%$ of pupils were boys. The median age of SSPE pupils was 9.4 years and $64 \%$ were boys [26, 31].

\section{Measures}

The participating schools used a digital school absence registry to record each pupil's absence daily. The school year 2015-2016 was analysed retrospectively. The school absence registry only contained those pupils recorded as absent, meaning that the number of pupils who were not absent in the chosen school year was not recorded. In order to determine the one-year prevalence of absence, the total number of pupils attending the school at the end of the school year was used.

Three types of authorised and two types of unauthorised absence were categorised: authorised comprised 
sickness absence, doctor's visits and other authorised absence (such as family holidays or events requiring approval from the principal); unauthorised comprised tardiness and all other unauthorised absence, e.g. truancy.

When reported sick, pupils were labelled as sick either occasionally or extensively based on the definition of extensive sickness absence by Vanneste et al. of more than nine school days or more than four periods in a school year [29]. A period of absence is a single continuous span of time during which a pupil is absent. As soon as a pupil is registered as back in school, this period ends.

The frequency and duration (in half days) of all types of sickness absence, other authorised absence and other unauthorised absence were analysed. Additionally, the absence rate each of these absence types was determined, based on an estimated total of 180 possible school days in a school year. The absence rate is the ratio of absence days to possible school days. The duration of doctors' visits and tardiness is not recorded by schools, therefore, only the frequency of these types of absence was analysed.

The month and year of birth, sex, years, and parental educational score of MPS pupils were collected from the school absence registry. Only the sex and the date of birth of pupils were available from SSPEs.

Age was calculated at the end of the school year based on the pupil's month and year of birth.

For years MPS groups were made by combining lower years (Dutch school years one and two when pupils are normally four or five years-old), middle years (three, four and five) and senior years (six, seven and eight). Several schools had combination classes with different years in one class. These were allocated to the group of the highest year in each combination class.

The parental educational score was based on the parents' highest educational achievement [32]. It was converted into a binary variable: category zero for parents with an education up to, or the equivalent of, prevocational education in the Netherlands, and category one for parents with a higher educational achievement than prevocational education.

\section{Analysis}

Due to the variation in selection methods, data from MPSs and SSPEs were analysed separately. $x^{2}$ and Mann-Whitney $U$ tests were used to analyse differences in occurrence of absence in MPSs and SSPEs. Univariate and multiple logistic regression analyses were used to determine the association between extensive sickness absence and (i) pupil characteristics (ii) other types of absence, and compared with occasional sickness absence.
The data were structured hierarchically, with pupils (first level) nested within schools (second level). In order to test if it was necessary to control for school effect in the analyses, the intra-class correlation coefficient (ICC) was determined [33, 34]. The ICCs for sickness absence ranged from .02 for MPSs to .07 for SSPEs, thus less than $8 \%$ of the variation in sickness absence in this sample was due to differences between schools, indicating that controlling for school effects was unnecessary.

\section{Results}

\section{Study population}

In MPSs $50 \%$ of pupils recorded in the absence registry were male, in SSPEs this was $64 \%$. The mean age of pupils in SSPEs recorded in the absence registry was significantly higher than in MPSs (Median SSPEs: 9.64, MPSs: 7.95, Mann-Whitney test: $\mathrm{U}=774.774 .5$, $p \leq .001$ ). Each MPS group (lower, middle and senior) contained approximately $33 \%$ of the pupils. A low parental educational score was found in 6\% of MPS pupils. Concerning school size, the MPSs had an average of 277 pupils and the SSPEs an average of 167 pupils.

\section{Prevalence of school absenteeism}

Of the 2216 pupils in MPSs, 85.70\% (1877) were recorded as absent in the school year 2015-2016 (Fig. 1). In SSPEs $79.10 \%$ of the pupils (791) were recorded as absent. Sickness absence was the most frequently found (Table 1). In MPSs, $75.04 \%$ of pupils (1663) were reported sick at least once. Records showed that these pupils had a median of two periods of sickness (maximum of 31 periods), and three days (maximum of 45 days) in the school year. In SSPEs, $70.80 \%$ of pupils (708) were reported sick at least once during the year, with a median of three periods and four days of sickness absence (maximum: 28 periods and 80 days). Extensive sickness absence was recorded in $13.13 \%$ of MPS pupils and $22.50 \%$ of SSPE pupils. Unauthorised absence was the least prevalent type of absence. Other than tardiness, unauthorised absence was recorded in $1.81 \%$ of MPS pupils and $8.00 \%$ of SSPE pupils. The frequency and duration of types of school absence are shown in Table 2.

Focusing on absence rates, the total absence rate in MPSs was $2.15 \%$ and the sickness absence rate was $1.80 \%$. The rate of other authorised absence was $0.34 \%$ and that of other unauthorised absence was $0.01 \%$. In SSPEs the absence rates were $2.85,2.45,0.31$ and $0.09 \%$, respectively.

When comparing sickness absence in SSPEs with MPSs, SSPE pupils were reported sick significantly more often (median SSPEs: 3, MPSs: 2, Mann-Whitney test: $\mathrm{U}=696.175,500, p \leq .001$ ), and for longer (median 


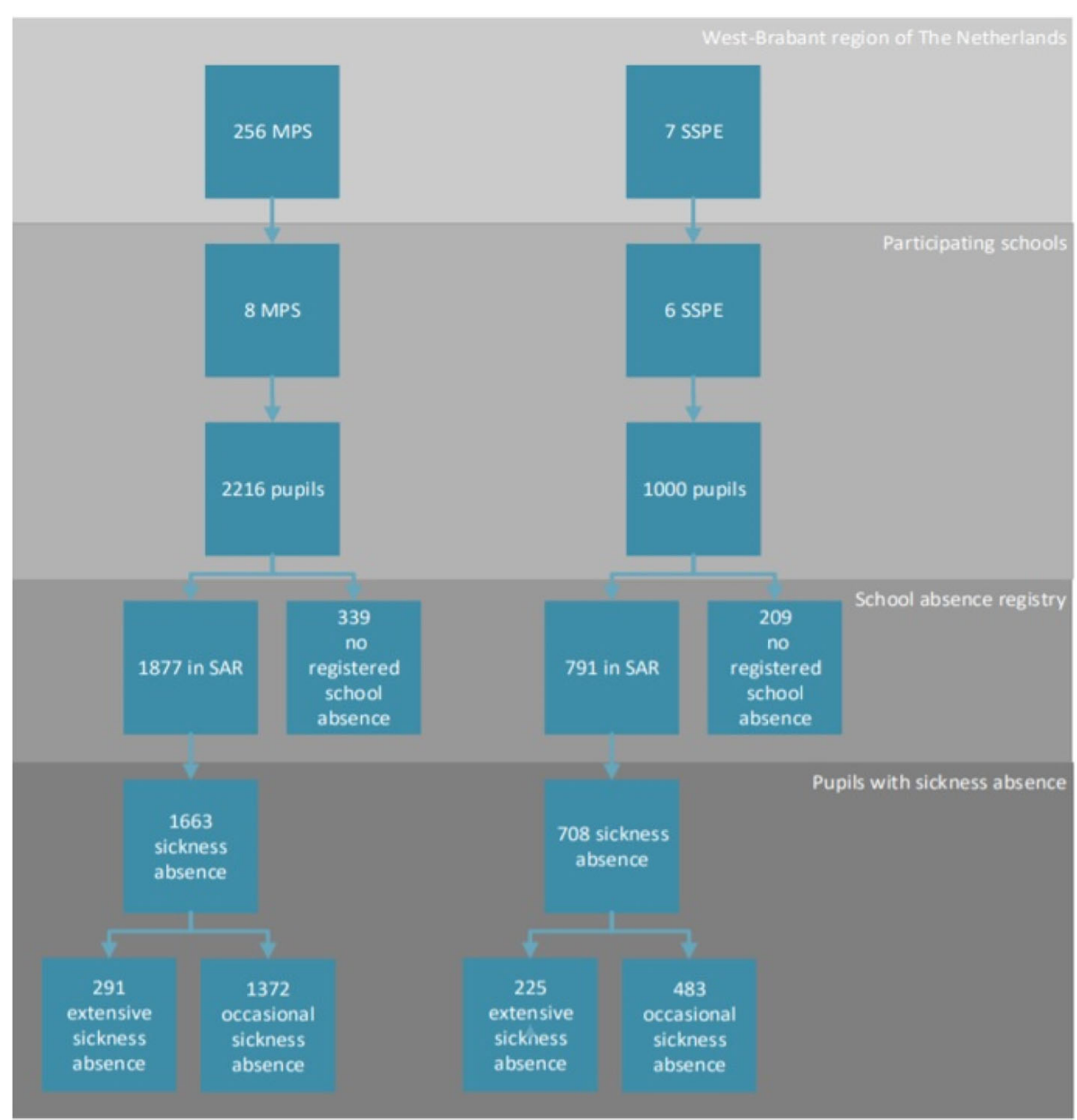

Fig. 1 Overview of regular primary schools and pupil population in the region of West-Brabant

Table 1 Types of school absence in primary education in the school year 2015/2016

\section{Type of school absence}

\begin{tabular}{|c|c|c|}
\hline & $N=2216$ & $N=1000$ \\
\hline Sickness absence & $1663(75.0) *$ & $708(70.8)$ \\
\hline Occasional sickness absence & $1372(61.9) \dagger$ & $483(48.3)$ \\
\hline Extensive sickness absence & $291(13.1)+$ & $225(22.5)$ \\
\hline One or more long period of sickness absence ( $>9$ days and $<4$ periods) & $42(1.9) \dagger$ & $19(1.9)$ \\
\hline High frequency of sickness absence ( $>4$ periods and $<9$ days) & $129(5.8)+$ & $79(7.9)$ \\
\hline $\begin{array}{l}\text { Both long periods of sickness absence and high sickness absence frequency ( }>9 \text { days } \\
\text { and }>4 \text { periods) }\end{array}$ & $120(5.4)+$ & $127(12.7)$ \\
\hline Doctor's visits & $574(25.9) * *$ & $314(31.4)$ \\
\hline Other authorised absence & $539(24.3)+$ & $337(33.7)$ \\
\hline Tardiness & $219(9.9) * *$ & $135(13.5)$ \\
\hline Other unauthorised absence & $40(1.8)+$ & $80(8.0)$ \\
\hline
\end{tabular}

MPS: Number of pupils SSPE: Number of pupils (\%) 
Table 2 Frequency and duration of school absence among pupils in primary education in the school year 2015/2016

\begin{tabular}{|c|c|c|c|c|c|c|c|}
\hline & & \multicolumn{3}{|c|}{ MPS (total N pupils:2216) } & \multicolumn{3}{|c|}{ SSPE (total N pupils:1000) } \\
\hline & & Mean (SD) & Median & Range & Mean (SD) & Median & Range \\
\hline \multirow[t]{2}{*}{ Sickness absence } & Duration (days) & $4.30(4.44)$ & $3+$ & $0.5-63$ & $6.24(6.94)$ & 4 & $0.5-80$ \\
\hline & Frequency & $2.73(2.36)$ & $2+$ & $1-31$ & $3.74(3.26)$ & 3 & $1-28$ \\
\hline Doctor's visits & Frequency & $2.18(3.13)$ & $1+$ & $1-35$ & $2.39(1.87)$ & 2 & $1-12$ \\
\hline \multirow[t]{2}{*}{ Other authorised absence } & Duration (days) & $2.52(4.15)$ & $1 \dagger$ & $0.5-62.5$ & $1.65(1.60)$ & 1 & $0.5-12$ \\
\hline & Frequency & $1.85(2.86)$ & $1+$ & $1-56$ & $1.73(1.99)$ & 1 & $1-24$ \\
\hline Tardiness & Frequency & $4.91(8.44)$ & $2+$ & $1-66$ & $4.55(6.59)$ & 2 & $1-43$ \\
\hline \multirow[t]{2}{*}{ Unauthorised absence } & Duration (days) & $1.05(0.98)$ & $1 \dagger$ & $0.5-5.5$ & $1.93(2.56)$ & 1 & $0.5-13.5$ \\
\hline & Frequency & $1.15(0.43)$ & $1 \dagger$ & $1-3$ & $1.86(2.36)$ & 1 & $1-14$ \\
\hline
\end{tabular}

MPS: Mainstream primary schools

SSPE: Special schools for primary education

† Significant difference between MPS and SSPE at 95\% confidence interval $p<0.001$

SSPEs: 4, MPSs: 3, Mann-Whitney test: $\mathrm{U}=701.361,500$, $p \leq .001)$ than MPS pupils. The rate of extensive sickness absence was significantly higher in SSPEs than in MPSs $\left(\chi^{2}(1)=59.483, p<=.001\right)$.

\section{Factors associated with extensive sickness absence}

Table 3 shows the results of both univariate and multivariate logistic regression analyses. Only the variables that were statistically significant in the univariate analysis were included in the multivariate logistic regression analysis. Multivariate analysis of extensive sickness absence among MPS pupils showed a statistically significant relationship with lower age, lower parental educational score, doctor's visits, and other unauthorised absence, when compared with pupils with occasional sickness absence. Among SSPE pupils all other types of school absence showed a statistically significant relationship with extensive absence. This indicates that in addition to extensive sickness absence, these pupils are also more often reported absent for other reasons.

\section{Discussion}

This study was performed in eight MPSs with 2216 pupils and six SSPEs with 1000 pupils in order to gain insight into the prevalence of school absence and the relationship between extensive sickness absence and pupil characteristics and other types of school absence.

\section{Prevalence of school absenteeism}

Most pupils, 85\% in MPSs and 79\% in SSPEs, were absent at least once during the school year, with total school absence rates of 2.1 and $2.9 \%$, respectively. The most common type of absence from school in primary schools was absence due to sickness: $75 \%$ of MPS pupils and $71 \%$ of SSPE pupils were reported sick at least once in the school year, with sickness absence rates of 1.8 and $2.5 \%$, respectively. While comparable research is limited, reports from Scotland and England were available and show similar figures with total school absence rates of $5.0 \%$ in Scotland and 4.0\% in England, and sickness absence rates of 2.9 and $2.4 \%$, respectively $[35,36]$.

Table 3 Logistic regression analysis of factors associated with extensive sickness absence (versus occasional sickness absence)

\begin{tabular}{|c|c|c|c|c|c|c|c|c|c|c|}
\hline & \multicolumn{5}{|l|}{ MPS } & \multicolumn{5}{|l|}{ SSPE } \\
\hline & \multirow{2}{*}{$\begin{array}{l}\text { Number } \\
\text { of Pupils }\end{array}$} & \multicolumn{2}{|c|}{ Univariate } & \multicolumn{2}{|c|}{ Multivariate } & \multirow{2}{*}{$\begin{array}{l}\text { Number } \\
\text { of Pupils }\end{array}$} & \multicolumn{2}{|c|}{ Univariate } & \multicolumn{2}{|c|}{ Multivariate } \\
\hline & & $\operatorname{Exp}(B)$ & $\mathrm{Cl}$ & $\operatorname{Exp}(B)$ & $\mathrm{Cl}$ & & $\operatorname{Exp}(B)$ & $\mathrm{Cl}$ & $\operatorname{Exp}(B)$ & $\mathrm{Cl}$ \\
\hline $\operatorname{Sex}^{\diamond}$ & 1525 & 0.98 & $0.75-1.28$ & - & - & 705 & 0.98 & $0.70-1.37$ & - & - \\
\hline Age & 1513 & $0.93^{*}$ & $0.89-0.99$ & $0.92^{*}$ & $0.87-0097$ & 589 & 1.01 & $0.93-1.10$ & - & - \\
\hline Low parental education level & 1524 & $2.00^{*}$ & $1.25-3.18$ & $1.66^{*}$ & $1.01-2.72$ & - & - & - & - & - \\
\hline Doctor's visits • & 1530 & $2.14^{* *}$ & $1.63-2.83$ & $2.26^{* *}$ & $1.69-3.01$ & 708 & $1.63^{* *}$ & $1.18-2.25$ & $1.48^{*}$ & $1.05-2.08$ \\
\hline Other authorised absence - & 1530 & $1.42^{*}$ & $1.06-1.89$ & 1.21 & $0.90-1.64$ & 708 & $1.94^{* *}$ & $1.41-2.68$ & $1.90^{* *}$ & $1.36-2.65$ \\
\hline Tardiness • & 1530 & 1.22 & $0.80-1.85$ & - & - & 708 & $2.67^{* *}$ & $1.79-3.99$ & $2.35^{* *}$ & $1.54-3.59$ \\
\hline Other unauthorised absence - & 1530 & $5.06^{* *}$ & $2.38-10.74$ & $4.58^{* *}$ & $2.08-10.11$ & 708 & $3.22^{* *}$ & $1.98-5.23$ & $2.75^{* *}$ & $1.66-4.54$ \\
\hline
\end{tabular}

MPS: Mainstream primary schools, SSPE: Special schools for primary education, $\mathrm{Cl}$ : Confidence Interval

$\checkmark$ reference: male

- having any of this type of absence at least once during the academic year 2015/2016. Reference: having none of this type of absence

${ }^{*} P<0.05,{ }^{* *} P<0.01,95 \%$ confidence interval 
In the current study, unauthorised absence occurred rarely in MPSs (1.8\% of pupils) and more frequently in SSPEs (8.0\%). However, even $8 \%$ in SSPE seems low when considering that research often focuses on unauthorised absence [2, 18]. In Dutch, Scottish and English primary schools, sickness absence is clearly the most prevalent type of absence. Although comparison of prevalence between studies is difficult as findings may be influenced by differing selection methods, type of school and the way absence is measured. In the USA Cook et al. developed a primary school absence programme and found that only $47 \%$ of all absences were authorised [24]. Sickness absence was not specifically mentioned. The high prevalence of sickness absence and low prevalence of unauthorised absence found in the current study might be explained by the fact that it is easy to report a child as sick in the Netherlands, and it may be more convenient for a parent to report their child as sick than explain unauthorised absence to the authorities.

\section{Extensive sickness absence}

This study found that extensive sickness absence occurred frequently: $13 \%$ of MPS pupils and $22.5 \%$ of SSPE pupils were reported sick for more than four periods or more than nine days.

The current study showed that extensive sickness absence in MPSs occurred more often in younger pupils, and where parents had a lower educational level. A young age has previously been described as related to chronic school absence [6]. The relationship between extensive sickness absence and age may be due to childhood diseases in younger children [6,37], or may be related to the start of mandatory attendance. Dutch primary education starts at four years-old and lasts eight years [38], however, the first year is not mandatory. The relationship found between a lower parental educational score and extensive sickness absence is in line with other studies that also found parental education and lower socio-economic status were associated with more absence from school [10, 18, 25].

In SSPEs, extensive sickness absence is associated with all other types of school absence, irrespective of pupil age. In MPSs extensive sickness absence is associated with more doctor's visits and unauthorised absence. In addition to days missed due to extensive sickness absence, pupils miss even more days in school for other reasons, when compared with those who are only reported sick occasionally.

\section{MPS vs. SSPE}

Compared with MPS, SSPE pupils were slightly less often reported as absent (85\% vs $79 \%$, respectively) or sick $(79 \%$ vs $71 \%)$. However, regarding the subsamples of sickness absence, the sickness absence frequency and duration was higher in SSPEs than in MPSs. The reasons for attending SSPE, e.g. behavioural, learning and parental factors, have previously been described as influencing school absence [10], and thus the differences in the frequency and duration of sickness absence between MPS and SSPE might be explained by these factors. Whether behavioural, learning or parental factors cause sick reporting either directly or through increased vulnerability to illness, is unknown.

\section{Strengths and limitations}

As the age and sex distribution of pupils in the absence registry (MPSs: 7.95 years-old, 50\% boys, SSPEs: 9.64 years-old, 64\% boys) were all similar to their national equivalent (MPS: 7.87 years-old, 51\% boys, SSPE: 9.57 years-old and $67 \%$ boys) [26, 31], the results of this study appear to be generalisable to those in other areas in the Netherlands.

To determine the occurrence of school absence, the total number of pupils at the end of the school year were used, rather than the total at the start. As more pupils enrol than leave during the school year, the totals at the start of the school year would have given an overestimation of absence. However, as late enrolees have less opportunity to be absent, using the end of the school year means that school absence might be even higher than found in this study.

In this sample, the average school size (MPS: $277 \mathrm{pu}$ pils and SSPE:167 pupils) was moderately larger than the national average (MPS: 224 pupils and SSPE: 122 pupils), and prevalence of MPS pupils with a low parental educational score $(6 \%)$ was lower than the national average of 9\% [32]. As a larger school size has previously been shown to be related to more school absence [9], and a low educational score was associated with more extensive sickness absence, the national prevalence of extensive sickness absence may well be even higher than found in this study.

Schools that did not agree to participate in this study stated time constraints and once, low prevalence of sickness absence among pupils as the main reason. It is unknown whether the prevalence of school absence in these schools is actually different.

\section{Extensive sickness absence}

Using a threshold for extensive sickness absence creates the opportunity to compare groups. The design of the threshold used in this study was based on interviews in schools and theorised that the pupils most at risk of negative consequences were those with sickness absence 1SD above the average sickness absence frequency or duration (as reported in a pilot study) [29]. As the groups selected in the current study had extensive 
sickness absence and missed additional days due to other types of absence, it appears that a vulnerable group was selected. Whether or not this threshold selects the most vulnerable pupils has not been tested.

\section{Absence registration}

The absence data were recorded daily by school employees and were collected retrospectively, thus minimising recall and information bias. Simultaneously, using retrospective analyses left no opportunity to improve the accuracy of recording absence. According to participating schools, not all teachers recorded every absence. Tardiness in particular might be subject to underreporting as not all schools expect punctuality. Previous studies have reported on the variations in recording practices $[24,35,39]$, therefore it is not unlikely that this may also have caused underreporting in the current data. The size of the current sample, i.e. 14 schools with 3216 pupils, minimises the effect of individual recording mistakes.

\section{Recommendations for further research}

Most absence in the participating Dutch primary schools was because pupils were reported sick, which is similar to reports from Scotland and England [35, 36]. Traditionally, the focus of research into school absence has been on unauthorised absence, possibly because of a lower prevalence of sickness absence in other countries such as the USA. Another explanation could be that, as its cause seems medical, sickness absence is seen as inevitable. However, this study suggests that learning, behavioural and parental factors may also play a role. More research is therefore needed to determine the prevalence of sickness absence in other countries and to determine the factors that influence sickness absence. Countryspecific approaches to defining, recording and addressing school absence should be taken into account when examining this topic.

The threshold used for extensive sickness absence should be further examined to determine if those pupils who are most vulnerable to adverse outcomes can be selected using these criteria, and if these criteria should be adjusted when used in other countries.

\section{Conclusions}

This study shows that in Dutch primary education school absenteeism is most often due to children being reported sick. Moreover, extensive sickness absence is common (13.1\% in MPSs and $22.5 \%$ in SSPEs), and occurred more often in SSPE pupils than in MPS pupils. In MPSs, younger pupils and pupils with parents with a lower educational level appeared most at risk of extensive sickness absence. Additionally, in comparison with pupils with occasional sickness absence, pupils with extensive sickness absence were absent on more days for reasons other than sickness. Thus, these pupils miss even more days of school, likely increasing their disadvantage by missing lessons and contact with their peers. Combined with the high prevalence of extensive sickness absence found in this study, this is reason to worry. To prevent adverse effects on children's development it is of utmost importance that public health research, policy and practice address sickness absence among primary school pupils.

\section{Abbreviations \\ ICC: intra-class correlation coefficient; MPS: mainstream primary school; SD: standard deviation; SSPE: special school for primary education}

\section{Acknowledgements}

The authors would like to thank all collaborating partners. In particular all participating primary schools for digging up the school absence data. This study was conducted as thesis research for the first author's training as a medical specialist in public health at the Netherlands School of Public and Occupational Health.

\section{Authors' contributions}

All authors were involved with the study design. EP and $\mathrm{Y}$ included the schools and collected data, EP and JM analysed data and EP drafted the manuscript. All authors critically reviewed and revised the manuscript. All authors read and approved the final manuscript.

Funding

No research grants were used for this work. The research was funded by the GGD West-Brabant as part of the first author's training as medical specialist in public health.

\section{Availability of data and materials}

The dataset generated and analysed during the current study is not publicly available due to data protection rules but can be made available from the corresponding author on reasonable request.

\section{Ethics approval and consent to participate}

The study was approved of by the Medical Research Ethics Committee (METC) of the Academic Hospital Maastricht/Maastricht University (METC 174-026). The research was conducted in accordance with the 1964 Declaration of Helsinki and its later amendments [40].

Consent for publication

Not applicable.

\section{Competing interests}

The authors declare that they have no competing interests.

\section{Author details}

${ }^{1}$ Child and Youth Healthcare Department, GGD West-Brabant, Breda, The Netherlands. ${ }^{2}$ Department of Social Medicine, Faculty of Health Medicine and Life Sciences, Care and Public Health Research Institute (CAPHRI), Maastricht University, Maastricht, The Netherlands. ${ }^{3}$ Dutch Knowledge Centre for Youth Health (NCJ), Utrecht, The Netherlands. ${ }^{4}$ Academic Collaborative Centre Youth, Tranzo, Tilburg University, Tilburg, The Netherlands.

Received: 14 April 2020 Accepted: 7 January 2021

Published online: 20 January 2021

\section{References}

1. Olatunya OS, Oke OJ, Kuti BP, Ajayi IA, Olajuyin O, Omotosho-Olagoke O, et al. Factors influencing the academic performance of children with sickle cell Anaemia in Ekiti. South West Nigeria. J Trop Pediatr. 2018;64(1):67-74.

2. Kearney CA, Bensaheb A. School absenteeism and school refusal behavior: a review and suggestions for school-based health professionals. J Sch Health. 2006;76(1):3-7. 
3. Malcolm H, Wilson V, Davidson J, Kirk S. Absence from school: a study of its causes and effects in seven LEAsGlasgow; 2003.

4. Theunissen M-J, Bosma H, Verdonk P, Feron F. Why wait? Early determinants of school dropout in preventive pediatric primary care. PLoS One. 2015 10(11):e0142315

5. Limperg PF, Joosten MMH, Fijnvandraat K, Peters M, Grootenhuis MA, Haverman L. Male gender, school attendance and sports participation are positively associated with health-related quality of life in children and adolescents with congenital bleeding disorders. Haemophilia. 2018 24(3): 395-404.

6. Allison MA, Attisha E. The link between school attendance and good health. Pediatrics. 2019;143(2):e20183648.

7. Schoeneberger JA. Longitudinal attendance patterns : developing high school dropouts. Clear House A J Educ Strateg Issues Ideas. 2012;85(1):7-14.

8. Ansari A, Pianta RC. School absenteeism in the first decade of education and outcomes in adolescence. J Sch Psychol. 2019;76(April):48-61.

9. Kearney CA. School absenteeism and school refusal behavior in youth: a contemporary review. Clin Psychol Rev. 2008;28:451-71.

10. Thornton M, Darmody M, McCoy S. Persistent absenteeism among Irish primary school pupils. Educ Rev. 2013 65(4):488-501.

11. Kesztyüs D, Wirt T, Kobel S, Schreiber A, Kettner S, Dreyhaupt J, et al. Is central obesity associated with poorer health and health-related quality of life in primary school children? Cross-sectional results from the BadenWürttemberg study. BMC Public Health. 2013;13(1):1-11.

12. Finning $\mathrm{K}$, Ford $\mathrm{T}$, Moore DA, Ukoumunne OC. Emotional disorder and absence from school: findings from the 2004 British child and adolescent mental health survey. Eur Child Adolesc Psychiatry. 2020;29(2):187-98.

13. Zhang $Y$, Cui $L, X u$ D, He MZ, Zhou J, Han L, et al. The association of ambient PM 2.5 with school absence and symptoms in schoolchildren: a panel study. Pediatr Res. 2018;84(1):28-33.

14. An R, Yan H, Shi X, Yang Y. Childhood obesity and school absenteeism: a systematic review and meta-analysis. Obes Rev. 2017 18(12):1412-24.

15. Fry D, Fang X, Elliott S, Casey T, Zheng X, Li J, et al. The relationships between violence in childhood and educational outcomes: a global systematic review and meta-analysis. Child Abuse Negl. $2018 ; 75: 6-28$.

16. Stempel H, Cox-Martin M, Bronsert M, Dickinson LM, Allison MA. Chronic school absenteeism and the role of adverse childhood experiences. Acad Pediatr. 2017 ;17(8):837-43.

17. Zhang M. Links between school absenteeism and child poverty. Pastor Care Educ. 2003;21(1):10-7.

18. Gubbels J. Risk factors for school absenteeism and dropout : a meta-analytic review. J Youth Adolesc. 2019.

19. Fleming M, Fitton CA, Steiner MFC, Mclay JS, Clark D, King A, et al. Educational and Health Outcomes of Children Treated for Type 1 Diabetes: Scotland-Wide Record Linkage Study of 766, 047 Children. 2019;1-8.

20. Mukherjee M, Stoddart A, Gupta RP, Nwaru Bl, Farr A, Heaven M, et al. The epidemiology, healthcare and societal burden and costs of asthma in the UK and its member nations: analyses of standalone and linked national databases. BMC Med 2016;

21. Ehrlich SB, Gwynne JA, Allensworth EM. Pre-kindergarten attendance matters: early chronic absence patterns and relationships to learning outcomes. Early Child Res Q. 2018;44:136-51.

22. Gershenson S, Jacknowitz A, Brannegan A. Are student absences worth the worry in U.S. primary schools? Educ Financ Policy. 2017;12(2):137-65.

23. Gottfried MA. Chronic absenteeism in the classroom context: effects on achievement. Urban Educ. 2019;53(1):3-34.

24. Cook PJ, Dodge KA, Gifford EJ, Schulting AB. A new program to prevent primary school absenteeism: results of a pilot study in five schools. Child Youth Serv Rev. 2017:82:262-70.

25. Vermeiren AP, Willeboordse M, Oosterhoff M, Bartelink N, Muris P, Bosma H. Socioeconomic multi-domain health inequalities in Dutch primary school children. Eur J Pub Health. 2018;28(4):610-6.

26. Ministry of Education, Culture and Science, Dienst uitvoering onderwijs $C$ bureau voor statisiek. Ontwikkeling van het aantal leerlingen in het primair onderwijs (Development of the number of pupils in primary education] [Internet]. Onderwijs in Cijfers. 2018 [cited 2019 Aug 12]. Available from: https://www.onderwijsincijfers.n//kengetallen/po/leerlingen-po/aantallenontwikkeling-aantal-leerlingen\#.

27. Brouwer-Borghuis ML, Heyne DA, Vogelaar B, Sauter FM. Early identification of school attendance problems: how helpful are Dutch laws, policies, and protocols? Eur J Educ Psychol. 2019;12(1):47.
28. NIPO het marktonderzoek. Rapport Schoolverzuim in het Voortgezet Onderwijs [Report on school absenteeism in secondary education]. Amsterdam, The Netherlands; 2002.

29. Vanneste YTM. Reported sick from school: a study into addressing medical absenteeism among students. The Netherlands: Maastricht; 2015.

30. Ministry of Education C and S. Speciaal onderwijs [Internet]. Rijksoverheid.nl Passend onderwijs. [cited 2019 Aug 11]. Available from: https://www. rijksoverheid.nl/onderwerpen/passend-onderwijs/speciaal-onderwijs

31. Centraal bureau van Statistiek (Central bureau of statistics). (Speciaal) basisonderwijs en speciale scholen; leerlingen, schoolregio [Internet]. Statline. 2019 [cited 2019 Aug 31]. Available from: https://opendata.cbs.nl/ statline/\#/CBS/nl/dataset/71478ned/table?ts=1567258843122

32. Culture and Science D uitvoering onderwijs $M$ of E. Toelichting Gewichtenregeling basisonderwijs per 1 januari 2015 [Internet]. 2015 [cited 2018 Jul 13]. Available from: http://www.jeugdinformatie.nl/nl/Download$\mathrm{NJi} / G e w i c h t e n r e g e l i n g t o e l i c h t i n g 2015 . p d f$

33. Shek DTL, Ma CMS. Longitudinal data analyses using linear mixed models in SPSS: concepts. Procedures and Illustrations. Sci World J. 2011;11:42-76.

34. Heinrich CJ, Lynn LE Jr. Means \& ends a comparative study of empirical methods for investigating governance \& performance. J Public Adm Res Theory. 2001;11(1):109-38.

35. National statistics, The Scottish Goverment. Summary statistics for schools in Scotland. Scotland; 2015

36. Department for Education, National Statistics. Pupil absence in schools in England: 2015 to 2016. England; 2017.

37. Byington CL, Ampofo K, Stockmann C, Adler FR, Herbener A, Miller T, et al. Community surveillance of respiratory viruses among families in the Utah better identification of germs-longitudinal viral epidemiology (BIG-LoVE) study. Clin Infect Dis. 2015;61(8):1217-24.

38. Nuffic. The education system of the Netherlands. The Hague, The Netherlands; 2019.

39. Keppens G, Spruyt B, Dockx J. Measuring school absenteeism: administrative attendance data collected by schools differ from self-reports in systematic ways. Front Psychol. 2019;10(December):1-10.

40. Williams JR. The declaration of Helsinki and public health. Bull World Health Organ. 2008;86(8):650-2.

\section{Publisher's Note}

Springer Nature remains neutral with regard to jurisdictional claims in published maps and institutional affiliations.

\section{Ready to submit your research? Choose BMC and benefit from:}

- fast, convenient online submission

- thorough peer review by experienced researchers in your field

- rapid publication on acceptance

- support for research data, including large and complex data types

- gold Open Access which fosters wider collaboration and increased citations

- maximum visibility for your research: over $100 \mathrm{M}$ website views per year

At $\mathrm{BMC}$, research is always in progress.

Learn more biomedcentral.com/submissions 